SOSIOLIUM

\title{
PEMBELAJARAN IPS BERBASIS KEARIFAN LOKAL (STUDI KASUS DI SMP NEGERI 1 JEPARA)
}

\author{
Shofiatun Ni'mah, Arif Purnomo, Aisyah Nur Sayidatun Nisa ${ }^{凶}$ \\ Prodi Pendidikan IPS, Fakultas Ilmu Sosial, Universitas Negeri Semarang, Indonesia
}

\begin{abstract}
Info Artikel
Sejarah Artikel:

Disubmit: Mei 2020

Direvisi: Juni 2020

Diterima: Juli 2020

\section{Keywords:}

local wisdom;social

science; contextual

Abstrak

Kurikulum 2013 bersifat kontekstual yang menuntut guru mengaitkan materi dengan lingkungan sekitar siswa. Penelitian ini bertujuan untuk membahas pengembangan pembelajaran IPS berbasis kearifan lokal di SMP N 1 Jepara. Metode penelitian yang digunakan dalam penelitian ini adalah metode kualitatif deskriptif. Hasil penelitian menunjukkan bahwa perangkat pembelajaran sudah disusun sesuai dengan Permendikbud. Pelaksanaan pembelajaran IPS berbasis kearifan lokal yang dilakukan yaitu dengan mengaitkan materi dan kearifan lokal Jepara seperti kondisi alam pantainya, hasil lautnya, hasil karyanya seperti seni ukira, Kain Troso, dan tradisi masyarakat seperti perang obor dan Lomban. Guru mengaitkannya secara spontanitas ketika ceramah dan disisipkan ketika diskusi menyesuaikan materi dan kondisi kelas serta tidak terpaku dengan RPP. Faktor pendukung melaksanakan pembelajaran IPS berbasis kearifan lokal yaitu: dukungan dari kepala sekolah, guru dan siswa serta Kearifan lokal Jepara yang dapat dijadikan sumber belajar. Pembelajaran IPS berbasis kearifan lokal menjadikan peserta didik lebih memahami materi, walaupun guru masih terhambat pada manajemen waktu.
\end{abstract}

\begin{abstract}
The 2013 curriculum is contextual in that it requires the teacher to relate the material to the environment around students. This study aims to discuss the development of local wisdom-based social studies learning in SMP N 1 Jepara. The research method used in this research is qualitative method. The results showed that the learning tools had been arranged in accordance with the Ministry of Education and Culture. The implementation of social science learning based on local wisdom is carried out by linking Jepara's material and local wisdom such as the natural conditions of its beaches, sea products, art carvings, Troso fabrics, and community traditions such as Perang Obor and Lomban. The teacher links it spontaneously when lecturing and inserted it when the discussion adjusts the material and class conditions, that is not fixated with the lesson plan. Supporting factors for implementing social science learning based on local wisdom are: support from the principal, teachers and students as well as Jepara's local wisdom which can be used as a learning resource. Social studies learning based on local wisdom makes the students have better understanding to the material, even though the teacher is still hampered by the time management.
\end{abstract}

(C) 2020 Universitas Negeri Semarang

\footnotetext{
Alamat korespondensi:

Gedung C1 Lantai 1 FIS Unnes

Kampus Sekaran, Gunungpati, Semarang, 50229

E-mail: arifpurnomo@mail.unnes.ac.id
}

E-ISSN 2685-4929 


\section{PENDAHULUAN}

Berlakunya Kurikum 2013 menuntut peserta didik menjadi lebih aktif, kreatif, dan inovatif dalam setiap pemecahan masalah di sekolahnya. Kurikulum 2013 bersifat kontekstual, yaitu kegiatan pembelajaran yang materinya dihubungkan dengan lingkungan sekitar masyarakat. Lingkungan merupakan media atau sumber belajar yang sesuai dengan apa yang terjadi dalam hidupnya sehingga peserta didik dapat memahaminya dengan lebih mudah. Guru dapat mengembangkan pembelajaran kontekstual dengan melakukan pembelajaran berbasis kearifan lokal yang ada di sekitar siswa. Guru dapat mengintegrasikan materi IPS dengan kearifan lokal agar siswa tertarik dan dapat memahami materi dengan baik sehingga hasil belajar siswa maksimal.

Kurikulum IPS 2013 untuk SMP/MTs dijelaskan, Ilmu Pengetahuan Sosial (IPS) merupakan mata pelajaran yang mengkaji tentang isu-isu sosial dengan unsur kajiannya dalam konteks peristiwa, fakta, konsep, dan generalisasi. Tema yang dikaji dalam IPS adalah fenomena-fenomena yang terjadi di masyarakat baik masa lalu, masa sekarang, dan kecenderungannya di masa-masa mendatang (Supardan, 2015: 17). Maka dari itu, pembelajaran berbasis kearifan lokal dapat digunakan dalam kegiatan pembelajaran IPS yang materinya sangat kompleks dan berhubungan dengan kehidupan masyarakat.

Kearifan lokal sendiri merupakan bagian dari masyarakat yang diyakini dan dipatuhi oleh masyarakat baik itu berupa nilai-nilai maupun hasil budaya yang diciptakan masyarakat seperti upacara adat, tradisi, bahasa, dan tarian asli dari masyarakat setempat. Menurut keterangan dari ketiga guru di SMP N 1 Jepara, kemajuan teknologi informasi serta penggunaan media sosial dapat menimbulkan kecendurangan peserta didik meniru budaya luar. Sehingga, guru perlu menanamkan nilai-nilai karakter termasuk nilai-nilai karakter yang trekandung dalam kearifan lokal Jepara. Ke arifan lokal yang dikaitkan dengan materi IPS meliputi hasil budaya khas Kota Jepara seperti tradisi Lomban, Perang Obor, Pesta Baratan. Serta hasil budaya lainnya seperti kain Troso, ukiran, dan sumber daya alam seperti pantai-pantai yang dapat dijadikan sumber belajar. Guru mengintegrasikannya dengan menyisipkan nilainilai kearifan lokal maupun dengan mencontohkan kearifan-kearifan lokal Jepara pada materi yang sesuai. Penerapan pembelajaran Berbasis Kearifan Lokal diterapkan oleh guru IPS di SMP N 1 Jepara bertujuan supaya peserta didik lebih memahami materi dengan mudah karena sesuai dengan apa yang terjadi dan dialami di lingkungan sekitarnya. Selain itu, juga bertujuan untuk menanamkan nilai-nilai kearifan lokal yang dapat mengembangkan karakter peserta didik serta mau melestarikan kearifan lokal Jepara yang mulai terancam punah dengan adanya nilai-nilai dan budaya baru di masyarakat yang terjadi akibat dari perkembangan Ilmu Pengertahuan dan Teknologi (IPTEK) yang semakin maju. Maka dari itu pembelajaran IPS berbasis kearifan lokal perlu diterapkan dalam kegiatan pembelajaran. Berdasarkan latar belakang diatas, maka judul yang diangkat peneliti yaitu: "Pengembangan Pembelajaran IPS Berbasis Kearifan Lokal (Studi Kasus di SMP Negeri 1 Jepara)".

Rumusan masalah dalam penelitian ini yaitu: 1) Bagaimanakah guru dalam mengembangkan perangkat pembelajaran IPS berbasis Kearifan Lokal di SMP N 1 Jepara?, 2) Bagaimanakah guru dalam mengimplementasikan pembelajaran IPS berbasis kearifan lokal di SMP N 1 Jepara?, 3) Apa saja faktor pendukung dan penghambat dalam pelaksanaan pembelajaran IPS berbasis kearifan lokal di SMP N 1 Jepara?.

Tujuan penelitian dalam penelitian ini yaitu, 1) Mengidentifikasi guru dalam merancang kegiatan pembelajaran IPS berbasis Kearifan Lokal di SMP N 1 Jepara, 2) Mengidentifikasi guru dalam mengimplementasikan pembelajaran IPS berbasis kearifan lokal SMP N 1 Jepara, 3) Mengidentifikasi apa saja faktor pendukung dan penghambat pembelajaran IPS Berbasis Kearifan Lokal di SMP N 1 Jepara.

Hasil Penelitian ini, dapat menambah wawasan bagi peneliti sebagai calon pendidik, serta menambah wawasan bagi guru mengenai pengembangan pembelajaran IPS dengan mengaitkan materi dan kearifan lokal.

\section{METODE PENELITIAN}

Penelitian ini merupakan penelitian Kualitatif Deskriptif. Metode kualitatif adalah penelitian yang bermaksud untuk memahami fenomena tentang apa yang dialami oleh subjek penelitian. Misalnya perilaku, persepsi, motivasi, tindakan dan lain-lain, secara holistik, dan dengan cara deskripsi dalam bentuk katakata dan bahasa, pada suatu konteks khusus yang alamiah dengan memanfaatkan berbagai metode alamiah (Moleong, 2007: 6). Tipe Penelitian kualitatif deskripstif mengumpulkan data berupa kata-kata, gambar dan bukan angka 
sesuai data di lapangan. Latar Penelitian ini yaitu di SMP Negeri 1 Jepara Lokasi SMP Negeri 1 Jepara berada di Jalan Sersan Sumirat, Jobokuto II, Kecamatan Jepara, Kabupaten Jepara. Peneliti memilih SMP N 1 Jepara sebagai tempat penelitian karena guru-guru IPS di sekolah tersebut sudah mengaitkan kearifan lokal dalam pembelajaran IPS. Selain itu, sekolah yang lokasinya dekat dengan pusat kota juga membuat peneliti ingin mengetahui bagaimana guru dalam mananamkan nilai-nilai kearifan lokal kepada peserta didik yang hidupnya di lingkungan pusat kota..

Fokus penelitian ini yaitu pengembangan perangkat pembelajaran IPS berbasis kearifan lokal, implementasi pembelajaran IPS berbasis kearifan lokal, serta faktor pendukung dan penghambat dalam melaksanakan pembelajaran IPS berbasis kearifan lokal. Sumber data dalam penelitian ini adalah sumber data primer yaitu guru IPS dan juga peserta didik, sedangkan sumber data sekunder berupa dokumendokumen dan arsip-arsip yang terdapat di SMP Negeri 1 Jepara dan sebagainya yang terkait dengan pelaksanaan pembelajaran IPS di sekolah.

Teknik pengumpulan data dilakukan dengan teknik observasi langsung, wawancara, dan juga dokumentasi. Observasi dilakukan dnegan mengamati secara langsung kegiatan pembelajaran di kelas. wawancara dilakukan untuk mendapatkan informasi dari guru dan peserta didik untuk mencocokkan dengan hasil observasi. Uji keabsahan data yang digunakan peneliti yaitu model interaktif berupa pengumpulan data, reduksi data, penyajian data, dan penarikan kesimpulan atau verifikasi.

\section{HASIL DAN PEMBAHASAN}

\section{Pengembangan Perangkat Pembelajaran Berbasis Kearifan Lokal}

Berdasarkan hasil penelitian, guru menyusun RPP sesuai dengan Permendikbud identitas sekolah, 2) nama pelajaran, 3) kelas/semester, 4) materi pokok, 5) alokasi waktu, 6) tujuan, pembelajaran 7) kompetensi dasar dan indikator pencapaian kompetensi, 8) materi pembelajaran, 9) metode pembelajaran, 10) media pembelajaran, 11) sumber belajar, 12) langkah-langkah pembelajaran, dan 13) penilaian hasil pembelajaran. Guru menyusunnya dengan cara menentukan materi kemudian disusun kegiatan pembelajarannya yang terdiri dari kegiatan awal, inti, dan penutup. Namun, karena kurangnya kreativitas dalam menyusun Rencana Pelaksanaan
Pembelajaran (RPP) membuat guru belum memunculkan unsur-unsur kearifan lokal secara tertulis. waktu juga menjadi kendala utama dalam penyusunan RPP. karena ketiga guru di SMP N 1 Jepara tidak hanya memiliki kesibukan mengajar IPS saja di sekolah namun adapula yang merangkap jabatan, sehingga membuat guru banyak kesibukan di luar mengajar.

Guru sudah mencantumkan nilai karakter yang harus di capai peserta didik di RPP karena menurut guru IPS di SMP N 1 Jepara, nilai karakter seperti gotong royong, kerjasama, toleransi, dan sebagainya juga merupakan nilai karakter yang terkandung dalam kearifan lokal Jepara.

\section{Implementasi Pembelajaran IPS Berbasis Kearifan Lokal Kegiatan Awal \\ Terdapat delapan ketrampilan dasar} dalam mengajar yang perlu diperhatikan guru untuk mencapai tujuan pembelajaran, menurut thurney dalam Mulyasa (2006), yaitu: bertanya, memberi penguatan, mengadakan variasi, menjelaskan, membuka dan menutup pelajaran, membimbing diskusi kelompok kecil, mengelola kelas, serta mengajar kelompok kecil dan perorangan. Kegiatan awal pembelajaran merupakan kegiatan sebelum guru menyampaikan inti dari materi pelajaran. Ketiga guru di SMP N 1 Jepara sendiri selalu mengawali pelajaran dengan berdoa. Berdoa salah satu upaya guru dalam menanamkan nilai religius kepada peserta didik agar selalu mengingat kepada Tuhan yme. Sehingga kegiatan pembelajaran IPS yang dilakukan berlangsung lancar. Kegiatan berdoa tersebut dipimpin oleh satu perwakilan dari peserta didik secara bergantian dan doanya sesuai dengan keyakinan yang dianut masing-masing peserta didik. Hal tersebut dapat memberikan pengertian kepada peserta didik bahwa mereka hidup berdampingan dengan keragaman termasuk agama yang berbeda-beda, sehingga mereka dapat saling menghargai satu sama lain.

Kegiatan setelah melakukan doa yaitu menyanyikan lagu Mars Jepara pada jam pertama di sekolah. Kegiatan tersebut ditujukan agar peserta didik dapat memahami isi dan arti dari isi lagu Mars Jepara sehingga dapat menumbuhkan rasa cinta dan kebanggannya terhadap Jepara. Lagu tersebut berisi mengenai potensi alam, seni ukiran, dan pahlawan wanita RA Kartini, serta slogan Kabupaten Jepara yaitu trus karyo tataning bumi yang artinya terus berkarya dalam hidup di bumi ini. Slogan 
tersebut dapat memotivasi peserta didik untuk terus belajar sehingga dapat menghasilkan karya dalam hidupnya.

Kegiatan selanjutnya yaitu laporan kepada guru siapa saja yang tidak hadir atau terlambat kelas, kemudian guru akan mereview materi di pertemuan sebelumnya. Jika peserta didik belum paham maka guru akan menjelaskannnya terlebih dahulu kemudian melanjutkan materi. Ketiga guru di SMP N 1 Jepara melakukan tahapan awal pembelajaran sesuai dengan aturan, namun jika waktu dan kondisi tidak memungkinkan maka akan langsung melanjutkan materi pelajaran tanpa pembukaan. Sehingga tidak banyak terjadi penyisipan nilai-nilai kearifan lokal melainkan hanya nilai-nilai seperti religi, dispilin, dan nasionalisme.

\section{Kegiatan Inti pembelajaran}

Permendikbud No. 81 A tahun 2013 lampiran IV menyatakan bahwa pembelajaran di sekolah tingkat dasar dikembangkan secara tematik, keterpaduan lintas mata pelajaran untuk mengembangkan sikap, ketrampilan, dan pengetahuan, serta mengapresiasi keragaman budaya lokal. Maka dari itu, sekolah dapat merealisasikannya dalam bentuk pembelajaran IPS berbasis kearifan lokal.

\section{Metode Pembelajaran}

Metode yang digunakan guru IPS di SMP N 1 Jepara yaitu ceramah, diskusi, dan tanya jawab. Metode diskusi dan tanya jawab diterapkan dalam pembelajaran agar peserta didik tetap aktif dan berpikir kritis.Sedangkan metode ceramah juga tetap dipilih guru dengan alasan peserta didik masih perlu arahan dan penjelasan materi terutama siswa kelas VII.

Penggunaan metode pembelajaran berkaitan erat dengan model pembelajaran yang dipakai, menurut Permendikbud No. 65 Tahun 2013 menyebutkan model pembelajaran yang diutamakan dalam kurikulum 2013 yaitu model pembelajaran inquiry, model pembelajaran berbasis proyek, model disvovery, dan model pembelajaran berbasis masalah. Guru IPS di SMP N 1 Jepara sering menggunakan model Problem Based Learning (PBL) dan juga Cooperative Learning meskipun belum maksimal pelaksanaannya.

Guru melaksanakan pembelajaran tidak terpaku dengan RPP, melainkan menyesuaikan situasi dan kondisi kelas. Meskipun begitu, guru IPS berusaha untuk tetap melaksanakan pembelajaran dengan baik sesuai dengan tujuan pembelajaran yang ingin di capai.

\section{Materi Pembelajaran}

Menurut Amri (2013), materi pembelajaran terdiri dari pengetahuan, sikap, dan ketrampilan yang dikembangkan berdasarkan Standar Kompetensi Lulusan (SKL), Standar Kompetensi (SK), dan Kompetensi Dasar (KD) pada standar isi yang harus dipelajari oleh siswa untuk mencapai tujuan pembelajaran. Prinsip-prinsip yang harus diterapkan dalam menentukan materi yaitu: relevansi, konsistensi (keajegan) dan kecukupan.

Guru IPS di SMP N 1 Jepara sudah menyesuaikan materi dengan $\mathrm{SK}, \mathrm{KD}$, dan standar isi yang ditandai dengan penyesuaian materi dan kearifan lokal. materi-materi tersebut yaitu:

a. Kelas IX: 1). perubahan sosial budaya yang dikaitkan dengan kodisi masyarakat sekitar dari waktu ke waktu seperti menjamurnya perusahaan asing yang mendirikan pabrik tekstil sehingga industri meubel ukiran kesulitan mencari tenaga kerja untuk bagian amplas. 2). Perdagangan internasional, dikaitkan dengan potensi negara Indonesia khususnya potensi alam pantai Jepara untuk tujuan pariwisata dan juga hasil budaya masyarakat Jepara, yang juga berkaitan dengan ekonomi kreatif seperti Batik, Troso, dan ukiran.

b. Kelas VIII: 1). Materi Pluralitas Mayarakat Indonesia, yang dapat dikaitkan dengan lingkungan sekitar siswa bahwa Jepara juga memilki masyarakat yang plural termasuk dalam hal agama ada agama Islam, Hindu, Kristen, dan Budha. Terdapat pula etnis asli Jawa dan juga pendatang seperti China, sehingga budaya masyarakat juga beragam juga ada Lomban, Memeden Gadu, Perang Obor, dan sebagainya. 2). Materi mengenai Kondisi Masyarakat Indonesia pada masa penjajahan dikaitkan dengan perlawanan RA Kartini pahlawan asli Jepara yang mempunyai semangat juang yang tinggi melawan penjajah. 3). Keunggulan dan keterbatasan antarruang dan pengaruhnya dalam kehidupan ekonomi, sosial, dan budaya, dikaitkan dengan keunggulan yang ada di daerahnya yaitu Jepara dengan pantai indahnya seperti Karimunjawa, Bandengan, dan Kartini, serta hasil budaya ukiran, batik, dan kain Troso.

c. Kelas VII: 1). Materi interaksi antarruang yang dikatkan dengan interaksi yang dilakukan antarwilayah di Jepara dengan keunggulan yang dimiliki masing-masing daerah, 2). Materi tentang potensi sumber daya alam dan kemaritiman Indonesia yang 
dikaitkan dengan Sumber Daya Alam berupa hasil laut ikan, dan udang serta hasil kebun berupa Durian dan Rambutan. 3). Keragaman etnik dan budaya, dikaitkan dengan kondisi penduduk di Indonesia yang plural. Jepara sendiri masyarakatnya mempunyai ciri khas berupa hasil kerajinan ukirnya. 4). Materi tentang kehidupan masyarakat Indonesia pada masa Kerajaan Islam, bisa dikaitkan dengan tokoh-tokoh penyebar agama Islam di Jepara dan peninggalan-peninggalan sejarah Islam seperti Masjid Mantingan yang merupakan masjid tersohor di Pulau Jawa setelah Masjid Agung Demak di waktu dulu. Masjid tersebut terdapat makam Sultan Hadhirin yang dianggap sebagai wali yang berjasa menyebarkan agama Islam.

Guru sudah menyesuaikan Materi IPS dengan kearifan lokal yang ada di Jepara, guru menyampaikannya tidak berpatokan pada RPP atau bahan ajar, namun hanya melihat di buku pegangan guru kemudian spontanitas disesuaikan dengan kearifan lokal dan hanya mengalir saja, sehingga guru belum maksimal di prinsip keajegan.

Prinsip kecukupan juga sudah dilakukan guru karena materi dan kearifan lokal saling berkaitan dan melengkapi serta sesuai dengan tujuan pembelajaran IPS, sehingga tujuan tersebut mendapat hasil maksimal.

\section{Media Pembelajaran}

Media pembelajaran merupakan alat yang digunakan guru untuk menjelaskan materi yang sedang dibahas. Media yang sering digunakan guru yaitu papan tulis, LCD, peta, globe, gambar-gambar dan video berkaitan dengan materi. seperti video tentang kehidupan para nelayan di laut, jual beli di pasar, dan juga perusahaan mebel pembuat Seni Ukiran. Guru juga terkadang memberikan video-video lucu seperti kartun agar siswa tidak merasa bosan dan jenuh.

\section{Sumber Pembelajaran}

Berdasarkan Peraturan Pemerintah (PP) Nomor 19/2005 tentang standar nasional pendidikan, yaitu pasal 17 ayat 1 menjelaskan bahwa kurikuum tingkat satuan pendidikan SDSMA atau bentuk lain yang sederajat dikembangkan sesuai dengan satuan pendidikan, potensi daerah, sosial budaya, dan peserta didik. Maka dari itu, guru dapat menjadikan lingkungan sekitar termasuk kearifan lokal Jepara sebagai sumber belajar. Namun, sekolah belum ada agenda untuk mengamati langsung di lapangan karena faktor waktu, sehingga guru mensiasati dengan cara mengamati dilapangan tetapi dalam bentuk tugas rumah. Selain itu guru juga meminta siswa untuk mencari informasi sebanyabanyaknya dari internet. Sehingga sumber belajar siswa lebih variasi selain menggunakan BukuKerja Siswa (BKS), dan buku paket.

\section{Kegiatan Penutup Pembelajaran}

Menurut Djamarah (2010) dalam jurnal Uulul Khakiim, dkk. (2016) menjelaskan bahwa terdapat empat komponen dalam dalam kegiatan meutup pembelajaran yaitu: meninjau kembali, mengevaluasi, dan tindak lanjut. Berdasarkan observasi, Ketiga guru di SMP N 1 Jepara melakukan kegiatan penutup pembelajaran dengan meninjau kembali materi yang sudah diterangkan dan menanyakan kepada peserta didik jika masih ada materi yang belum dipahami. Namun hal tersebut tidak selalu dilakukan karena menyesuaikan dengan situasi dan kondisi kelas, begitu juga kegiatan evaluasi pembelajaran. Penanamn nilai kearifan lokal dalam kegiatan penutup jarang dilakukan karena waktu yang singkat, sehingga guru hanya menyampaikan nasihat-nasihat kepada peserta didik.

\section{Faktor Pendukung dan Penghambat Menggunakan Pembelajaran IPS berbasis kearifan lokal Faktor Pendukung}

Faktor pendukung terdiri dari faktor internal dan eksternal. Faktor internal meliputi semua pihak sekolah terdiri dari kepala sekolah, guru, dan juga peserta didik. kepala sekolah SMP $\mathrm{N} 1$ Jepara mendukung pembelajaran IPS berbasis kearifan lokal dengan menyediakan sarana-prasarana yang mendukung kegiatan pembelajaran seperti LCD dan juga adanya AC sehingga membuat kegiatan pembelajaran menjadi lebih nyaman.

Dukungan dari semua pihak termasuk kepala sekolah, antarguru IPS, dan juga peserta didik juga sangat mendukung pembelajaran IPS berbasis kearifan lokal. Berdasarkan wawancara dan observasi, respon peserta didik sangat baik, mereka sangat tertarik dan antusias mengikuti pelajaran.

Faktor eksternal juga menjadi pendukung dalam melaksanaan pembelajaran IPS berbasis kearifan lokal, yaitu keraifan lokal Jepara mempunyai potensi yang dapat dijadikan sumber belajar untuk melaksanakan pembelajaran IPS berbasis kearifan lokal, seperti pantai-pantainya, hasil laut dan Kebun Durian, tradisi perang Obor dan Pesta Baratan, Lomban, hasil budaya berupa benda seperti Ukiran, Kain troso, dan Batik. 


\section{Faktor Penghambat}

Faktor penghambat dalam melaksanakan pembelajaran IPS berbasis kearifan lokal yaitu waktu. Jika mengajak siswa terjun langsung ke lapangan karena menyesuaikan waktu pelajaran di sekolah dan juga waktu di lapngan. Mengingat, beberapa kearifan lokal seperti upacara dan festival mempunyai waktu yang sudah ditentukan. Biaya juga diperlukan jika observasi langsung ke lapangan.

\section{KESIMPULAN}

Berdasarkan penelitian, perangkat pembelajaran RPP sudah dibuat dan dikembangkan sesuai kurikulum 2013 dari Permendikbud. Namun, kendala di waktu dan kurangnya kreativitas membuat guru belum mencantumkan perangkat yang memunculkan kearifan lokal, tetapi guru mencantumkan nilainilai karakter dalam RPP nya. ketiga guru SMP $\mathrm{N} 1$ Jepara sudah mengembangkan pembelajaran IPS berbasis kearifan lokal dengan melalui dua cara. pertama, guru mengaitkan materi dengan kearifan lokal seperti dengan pemberian contoh-contoh yang sesuai dengan kearifan lokal Jepara. Kedua, guru menyisipkan nilai-nilai karakter kearifan lokal Jepara seperti gotong royong, kerjasama, dan toleransi dalam kegiatan pembelajaran. guru mengaitkan materi dengan kearifan lokal secara spontan dan tidak terstruktur. Guru mengaitkan materi tersebut menggunakan metode ceramah, diskusi, dan tanya jawab.

Faktor yang mendukung pembelajaran ips berbasis kearifan lokal di SMP N 1 Jepara yaitu yang pertama, Kabupaten Jepara yang mempunyai keragaman sosial budaya dan potesi alam yang dapat menjadi sumber belajar siswa dan yang kedua yaitu semua pihak mendukung seperti kepala sekolah, guru-guru IPS dan juga siswa. Sedangkan faktor penghambatnya yaitu pertama, kesibukan guru menjadi faktor guru belum membuat perangkat pembelajaran berbasis kearifan lokal. Kedua, perlu waktu khusus dan juga biaya jika observasi langsung ke lapangan.

\section{DAFTAR PUSTAKA}

Amri, Sofan. 2013. Pengembangan dan Model Pembelajaran dalam Kurikulum 2013. Jakarta: PT. Prestasi Pustakaraya.

Khakiim, Uluul dkk. 2016. Pelaksanaan Membuka dan Menutup Pelajaran Oleh Guru Kelas 1 Sekolah Dasar. Jurnal pendidikan. Vo. 1, No. 9.

Moleong, Lexy J. 2007. Metodologi Penelitian Kualitatif. Bandung: PT Remaja Rosdakarya.

Peraturan Pemerintah (PP) Nomor 19/2005 Mengenai Standar Nasional Pendidikan

Permendikbud No. 22 Tahun 2016 Mengenai Standar Proses dalam Pendidikan.

Permendikbud No. 65 Tahun 2013 Mengenai Model Pembelajaran.

Permendikbud No. 81 A tahun 2013 Mengenai Pembelajaran di Sekolah Tingkat Dasar.

Rusman. 2014. Model-model Pembelajaran Mengembangkan Profesionalisme Guru. Jakarta: PT Rajagrafindo Persada. 